\title{
Reviews
}

\section{NIC MACLELLAN}

Journalist, researcher and community development worker in the Pacific Islands. He worked in Fiji between 1997-2000.

\section{An engaging analysis of core issues}

Government by the Gun: The Unfinished Business of Fiji's 2000 Coup, by William Sutherland and Robbie Robertson. Sydney: Pluto Press, 2001, 372 pp. ISBN:1 864031395.

ON 2 November 2000, I was returning home to Fiji after travelling overseas. Out of the blue, a phone call at the airport warned me that there was shooting at the Queen Elizabeth Barracks headquarters for the Fiji Military Forces in the capital, Suva. The quickest trip into town from Nausori airport runs past the barracks, but in true Fiji style, the taxi driver told me: "No worries!"

As we neared the barracks, however, and saw men armed with M16 rifles blocking the road, we decided discretion was the better part of val-

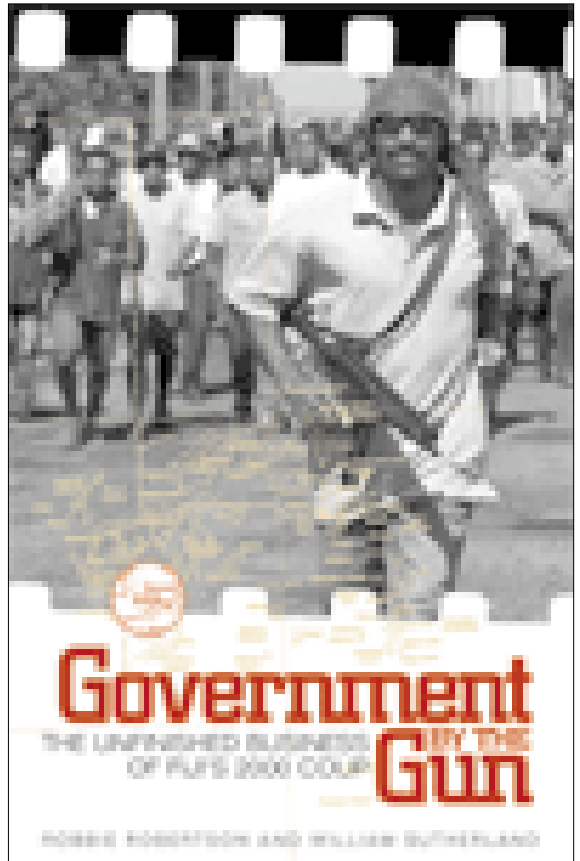

our. A quick U-turn and we took the back road in to town. Just another little drama in the weeks after the seizure of Parliament by George Speight and soldiers of the Counter Revolutionary Warfare Unit (CRWU) - or so I thought.

That night, we gathered at home with our neighbours, a young Fijian woman and a three-generation IndoFijian family. In the early evening, the clear night air carried sounds of a fierce firefight at the barracks: heavy 


\section{INDEX}

machine guns, rifle fire and explosions. We muttered calming platitudes, but unspoken was our fear that the attempted takeover of QEB by Speight supporters was spilling beyond the barracks.

This was the army divided — one of many Fijian institutions ripped apart by the events of May 2000. The death toll revealed next morning — three loyalist soldiers shot down in cold blood, and five CRWU rebels beaten to death by vengeful comrades - sent a chill through the community.

Many overseas journalists parachuted into Suva in the aftermath of the aborted putsch by George Speight and former SAS soldier Ilisoni Ligairi. Too many, wowed by Speight's charisma, parroted the mantra of "Fijians versus Indians" to explain the overthrow of the People's Coalition government led by Mahendra Chaudhry and the Fiji Labour Party.

Chaudhry, the first Indo-Fijian elected as Prime Minister since Independence in 1970, had certainly earned the enmity of extremists in the Fijian nationalist community. But the aftermath of the May 2000 coup and the army's abrogation of the Constitution on May 29 showed that a central core of the conflict was "Fijian versus Fijian".

This disunity was a fundamental difference between the coups of 1987 and 2000. Sitiveni Rabuka's 1987 takeover was backed by key Fijian institutions, including the army-made up largely of Fijian soldiers ever since World War Two. But George Speight's attempted takeover sowed discord in the judiciary, the Fiji Military Forces, the Methodist Church and the Bose Levu Vakaturaga (Great Council of Chiefs). In my own workplace, there were Fijians with family who were hostages and hostage takers; those who pledged allegiance to deposed President Ratu Sir Kamisese Mara or George Speight's favoured replacement Ratu Jopi Seniloli; those who welcomed the upset of the old chiefly established order and those who feared walking home in a climate that celebrated racism and power from the barrel of the gun.

These fundamental tensions within the indigenous community in Fiji are at the heart of this important new book: Government by the Gun.

William Sutherland, a former advisor and secretary to Dr Timoci Bavadra - the Fijian leader deposed in the 1987 coup - is the author of a key study of Fiji's political economy: Beyond the politics of race - an alternative history of Fiji (ANU, Canberra, 1992).

Robbie Robertson, with his partner Akosita Tamanisau, has long chronicled developments in Fiji, in books such as Fiji: Shattered Coups (Pluto Press, Leichhardt, 1988) and 176 PACIFIC JOURNALISM REVIEW 82002 
Multiculturalism and reconciliation in a reluctant republic - Fiji after the coups 1988-1998 (FIAPS/ USP, Suva, 1998).

Government by the Gun starts with a brief overview of the events of May 2000: the seizure of Parliament and government hostages; the military takeover, abrogation of Fiji's 1997 Constitution and dismissal of President Ratu Mara; weeks of tension, as the hostages are kept in Parliament for 56 days, a night-time curfew is instituted and Viti Levu suffers rolling power cuts after landowners seize the Monosavu hydro-electricity plant; the appointment of Laisenia Qarase as interim Prime Minister - undemocratic but welcomed by many, as the authors explain: "if nothing else, Qarase was organised and professional."

Beyond their summary of the May 2000 events, the importance of the book is its detailed analysis of Fijian nationalism and the quest for indigenous paramountcy. The authors highlight the contradictions between the demand for Fijian economic and political control in a country where half the population are descendants of Indian indentured labourers, Gujerati businessmen, European planters and a fruit salad of Chinese, islander and "part-European" communities.

The authors look at indigenous rights in the context of Fiji's communal politics, and attempts to create a democratic and multiracial society while dealing with the legacies of British colonial rule.

Dismissing the rhetoric of indigenous paramountcy, Sutherland and Robertson challenge the notion that all indigenous Fijians have common interests: "Certainly there are common bonds and shared interests but there are conflicting interests as well. The fundamental split is a class division between the elites on the one hand and the poor and disadvantaged on the other and cutting across this are tribal, provincial and regional splits. It has always suited the Fijian elite to hide their class interests behind the rhetoric of Fijian interests and paramountcy and blame the predicament of ordinary Fijians on others - namely the Indians."

\section{Privatisation and opposition}

A younger generation of Fijian scholars such as Alumita Duratalo and Sitiveni Ratuva are writing about the quixotic quest for Fijian unity. They have shown how the complex interplay between ethnicity and class benefits the Fijian chiefly and bureaucratic elite.

With the privatisation of government assets throughout the 1990s, a new generation of Fijian political and economic leaders has developed through the public service and statutory corporations. 


\section{INDEX}

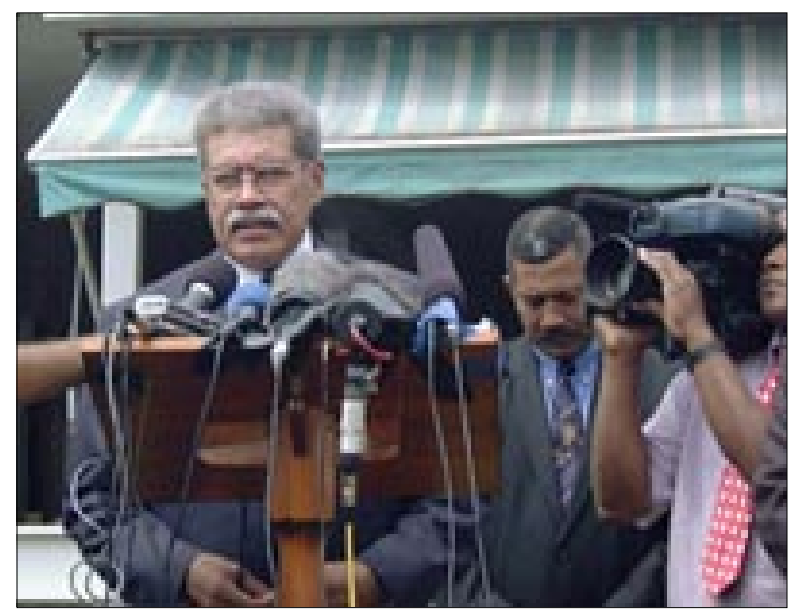

Qarase being sworn in as elected Prime Minister of Fiji.

Photo: Pacific Journalism Online (USP)

The transition from Ratu Mara to Laisenia Qarase symbolises this generational shift from chiefs to bankers: Mara, a chief from Lau in the Tovata confederacy, born and bred for leadership, relying on chiefly status as Tui Lau; Qarase, a seasoned veteran of the public service and finance sectors, former deputy chair of the investment company Fiji Holdings Ltd and managing director of the Fiji Development Bank (FDB) and the Merchant Bank of Fiji.

The People's Coalition government, elected in 1999, had challenged the economic legacy of Rabuka's Soqosoqo ni Vakavulewa ni Taukei (SVT) government. In 1993, the Rabuka government established a Commercialisation, Corporatisation and Privatisation Committee (CCPC) to implement its structural adjustment programme, with a sweeping agenda over electricity, ports, airport, public housing, timber and media.

However, a key feature of Fijian politics since the 1987 coups is the survival of the Fiji Trades Union Congress and the organised labour movement. Union, church and NGO activists in the Campaign Against the Privatisation of Water campaigned against the Rabuka government's 40 percent rise in water rates in January 1998 and challenged the sell-off of public assets. Union activists at the Civil Aviation Authority (CAA) resisted the sacking of 500 CAA employees at Nadi airport in 1999, as part of the privatisation of government services. These campaigns and the introduction of a Value Added Tax contributed to the massive swing to the People's Coalition in the May 1999 elections (the Labour-led Coalition removed VAT from essential foodstuffs, halted privatisation of government services, and started replacing the boards of statutory authorities).

Sutherland and Robertson argue that while the People's Coalition goals were reformist, not revolutionary, "its

178 PACIFIC JOURNALISM REVIEW 82002 
attacks on privatisation upset Fijian corporate interests who regarded privatisation as an important avenue for Fijianisation". George Speight, removed from the board of Fiji Hardwoods Corporation, was just one player unhappy with the Labour-led government, and willing to decry Chaudhry's policies as an attack on Fijian land, culture and "indigenous rights".

\section{Affirmative action - for all?}

The authors contend that indigenous Fijian rights were guaranteed in the 1997 Fiji Constitution introduced after the Reeves Commission inquiry. Most importantly, they develop an analysis of affirmative action policies introduced under Laisenia Qarase's Blueprint for Fijian Development, which "advantage the Fijian middle classes, not the disaffected masses that had fuelled the CRWU rebellion".

With extensive documentation, they argue that "from the history of the struggle for Fijian paramountcy, we learn that the main beneficiaries were not the vast majority of ordinary Fijians but the Fijian elite". Attempts to promote Fijian entrepreneurs focuss on grants to indigenous investment companies like Fiji Holdings Ltd — to the benefit of private shareholders.

Many grassroots Fijians got little from the affirmative action programmes of Rabuka's SVT through the 1990s, watching business and government scandals like the collapse of the National Bank of Fiji.

Government by the Gun argues that Laisenia Qarase will do little better to address the growing sense of grievance and uncertainty about the future among many rural and urban Fijian workers. The quest for Fijian unity has foundered, with a new spirit of provincialism manifested in tensions between the traditional Fijian confederacies of Kubuna, Tovata and Burebasaga, with calls for the creation of a new confederacy in the West the Yasayasa Vaka Ra.

In spite of the September 2001 electoral victory of Qarase's Soqosoqo Duavata ni Lewenivanua (SDL), the Labour Party has since won a series of court cases - still under appeal reaffirming their Constitutional right to participate in a multi-party Cabinet and to appoint members to the Senate. Like Pauline Hanson in Australia, Speight has now been pushed from the limelight. His conviction for treason, with a death sentence commuted to life imprisonment, marks an important transition. But like Hanson, Speight's charisma and savvy, amplified by uncritical media coverage, swept his ideas into the mainstream of political life.

\section{Indo-Fijian community splits}

Sutherland and Robertson rightly foPACIFIC JOURNALISM REVIEW 82002179 


\section{INDEX}

cus on the class and regional divisions in the indigenous Fijian community, but I feel their analysis of the coup is weakened by a lack of analysis of the same crisis in the Indo-Fijian community.

For decades, the dominant party for Indo-Fijians was the National Federation Party (NFP), which struggled for political and economic rights for the descendants of the girmitya indentured labourers (a process well documented in $A$ Vision for Change, Brij Lal's biography of NFP leader A.D. Patel). But since 1985, the Fiji Labour Party developed as a multiracial social democratic party. Under Mahendra Chaudhry, Labour has eclipsed the NFP's support in the Indo-Fijian community. In the 1999 and 2001 elections, the NFP was destroyed as an electoral force, with the Labour Party sweeping up virtually all the Indian communal seats. Efforts by a younger generation of NFP activists to rejuvenate the party - such as economist Dr Waden Narsey or union leader Attar Singh - have faltered in the face of entrenched opposition from an elite core of the NFP's business supporters.

Sutherland and Robertson are sympathetic to the Labour Party but not uncritical of its leader. A comprehensive history of Fiji after 1999 will need to analyse the conflict between Mahendra Chaudhry and Indo-Fijian businessmen and importers like Hari 180 PACIFIC JOURNALISM REVIEW 82002
Punja, Vinod Patel and Ramesh Solanki, and clashes with foreign investors in timber, gold and media. Chaudhry's long battle with the Murdoch-owned Fiji Times - which maintained a running attack on his short-lived government — is worth a study in itself!

Government by the Gun is a welcome addition to the burgeoning literature on Fiji - an engaged analysis that looks at the core of indigenous issues at the heart of Fiji's ongoing drama. 